\title{
The end of God
}

\author{
It's just common sense...
}

\section{Shelly Li}

Dear Heavenly Father: the plans I tried to carry through have failed. My mind has become my prison, betraying me to help them sever my connection with you. My family has been forced over to the other side, and I'm hurting, Lord. They hunt me by using my brain against me, and they do not stop. So all I ask for is hope, Lord.

Give me a plan.

The rustling outside the little shack makes my body tense up, and I rise to my feet, ready to run again.

My legs tense, my arms ache. And my heart, it has long depleted all longing. These things cease to become important when you are fighting for your identity against a monster that never sleeps.

Thirty years ago, when I was a child, and the World Trade Center hadn't been bombed, and the brain-signal satellites hadn't been set up, and the Common Sense Law hadn't been passed, prayers were beautiful. Prayers did not do things like activate the parietal lobe area of the brain and send messages to the satellites that an abstract idea was forming.

Prayers helped refocus my world.

Now, as I stumble to the back door, I see a world in which everything beautiful has blurred into a fog of grey.

God, you will help me

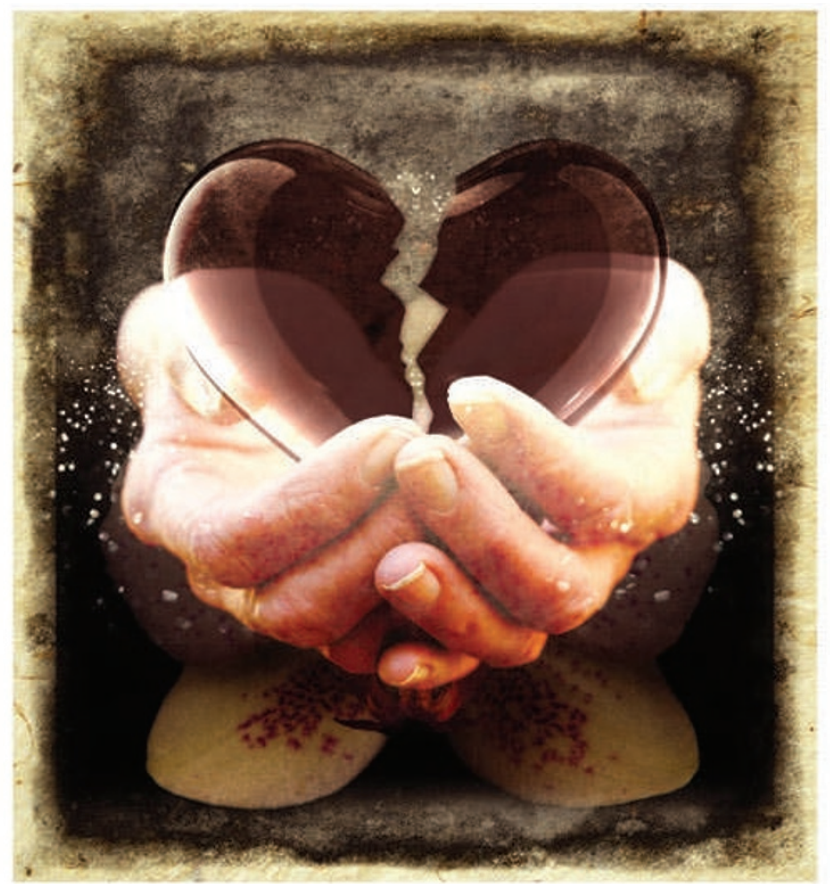

I look from officer to officer. They are nothing more than hunters. "Who are you to tell me whether or not I am allowed to be a child of God?"

"You're sicker than most, at this point," the young man says, and the others close in, moving to encircle me. "We could tell when we picked up signals of an abnormally excited IPL. We are here only to help cure you of your ... delusions."

"By forcing me to conform?" I let a laugh escape despite the tears pooling in my eyes. If this is a test, God, let the heathens deliver to me all the humiliation and fear they wish. In your name, I can absorb any pain. to me?" tell no lies.

eyes flutter open. Lying on a hospital bed with three doctors huddled over me, I attempt to move, but find that I've lost connection with even my fingers.

Stammering, I ask: "What have you done

But I know full well what has happened. The gnawing black hole in my chest can

"Don't worry," says an elderly woman doctor, setting a hand on my arm. I cannot feel the pressure. "The anaesthesia has worn off. What you are experiencing is probably shock. Most religious folk, after having their parietal-lobe area disabled, will feel a little disoriented for a while."

"At least you're all better now, no more illogical abstract ideas." One of the other doctors smiles down at me in the way that one usually stares at an ill patient. "How do you feel?"

I try to channel God.

Dear Heavenly Father, receive my apology. I let them force me, I let them take me in against my will and take you from me.

My eyes close, as I search for the familiar sense of warmth that sweeps into my chest at His acknowledgement, a reassurance that faith is not something that science can remove. No hacking or cutting from the hands of a mere man can separate me from you, Lord.

I refuse to believe it - I will not, cannot.

And yet, there is nothing but

"In accordance with the Common Sense Law, Sir, we must take you in and convert you. Please don't fight it."

"Faith means believing in something when common sense tells you not to," I reply, looking around. No one is moved. "And faith gives me a warmth that no amount of common sense ever will. Don't take this away from - "

Suddenly I feel a sharp sting in my neck as one policeman plunges a syringe into me.

"I'm sorry," the young policeman says.

A young man in police uniform appears. Behind him others follow as the white light from outside slices across their expressions, uniformly cold and faithless.

But when the young officer speaks, his tone fails to match the hardness of his gaze. "Sir, please come with us," he says, beckoning. "We will take you to a hospital and treat your ailment." the phantoms of silence.

Tears feel like they are falling from my eyes, stinging the sides of my cheeks. But my face remains dry.

So this is what it feels to be part of a whole. This is emptiness, loneliness, eating and ripping at the rim of your heart.

"Did you hear me?" the doctor's voice bleeds into my thoughts. "How do you feel?"

I blink and focus in on the reality before me and, realizing that even the surrounding colour in the world has dimmed, tell him: "My God has forsaken me. He has left me defenceless in a world populated by the lost and lonely."

Living in Omaha, Nebraska, Shelly went to church every Sunday until she was 12 . To learn more about her and her fiction, visit www.shelly-li.com. 